(1)

CrossMark

\title{
Healthcare workers with COVID-19 in Mexico
}

To the Editor:

I read with interest the recently published report by SIDDIQUi et al. [1], which described the characteristics and outcomes of health and social care workers testing positive for severe acute respiratory syndrome coronavirus 2 (SARS-CoV-2) in the Tayside region of Scotland.

Healthcare workers (HCWs) are at risk for SARS-CoV-2 infection $[1,2]$. The best way for HCWs to prevent infection with SARS-CoV-2 is through training and demonstrated competency in putting on and removing, also known as donning and doffing, personal protective equipment (PPE) [3]. In early April 2020, 22073 cases of coronavirus disease 2019 (COVID-19) among HCWs in 52 countries were reported to the World Health Organization [4]. This brief report highlights the risks facing frontline HCWs.

As of 28 June 2020, a cumulative total of 9843073 confirmed cases of COVID-19 have been reported worldwide [5]. As of this time, there have been 208392 total confirmed cases of COVID-19, including 25 779 resultant deaths, in Mexico [5]. A total of 46013 (22.08\%) Mexican HCWs have been infected with SARS-CoV-2. Most of them were between 30 and 54 years old. Among HCWs with COVID-19, 42332 (92\%) were not hospitalised, 1693 (3.67\%) were in critical condition, and 234 required endotracheal intubation and invasive mechanical ventilation $[6,7]$.

In Mexico, 92\% of affected HCWs had mild or moderate COVID-19, supporting the findings of SIDDIQUI et al. [1]. The case fatality rate of COVID-19 in HCWs based on all cases reported by the Mexican Secretariat of Health was $1.48 \%(683 / 46013)[6,7]$, as compared with an overall COVID-19 case fatality rate of $15.26 \%(25096 / 162379)$ (difference $13.78 \%$, 95\% CI 13.57-13.98\%; p<0.001).

PPE alone does not effectively protect patients and healthcare personnel. The way to ensure safe PPE use is through consistent and correct use reinforced by repeated training and practice. Finally, Mexican HCWs could have acquired SARS-CoV-2 infection at work through direct or indirect contact with infected patients, and HCWs could be exposed to infected family members, and colleagues, or live in an area with active community transmission $[2,8]$.

@ERSpublications

Healthcare workers can be infected in the community, and in interactions with colleagues; therefore, such infections are not always the result of acquisition from infected patients https://bit.ly/30opbTk

Cite this article as: Namendys-Silva SA. Healthcare workers with COVID-19 in Mexico. Eur Respir J 2020; 56: 2002885 [https://doi.org/10.1183/13993003.02885-2020].

Silvio A. Ñamendys-Silva $\oplus^{1,2}$

${ }^{1}$ Instituto Nacional de Ciencias Medicas y Nutricion Salvador Zubiran, Mexico City, Mexico. ${ }^{2}$ Instituto Nacional de Cancerología, Mexico City, Mexico.

Correspondence: Silvio A. Namendys-Silva, Instituto Nacional de Ciencias Medicas y Nutricion Salvador Zubiran, 14080, Mexico City, Mexico. E-mail: snamendys@gmail.com

Received: 23 July 2020 | Accepted after revision: 27 July 2020

Conflict of interest: S.A. Ñamendys-Silva has nothing to disclose.

\section{References}

1 Siddiqui MK, Parcell B, Allstaff S, et al. Characteristics and outcomes of health and social care workers testing positive for SARS-CoV-2 in the Tayside region of Scotland. Eur Respir J 2020; 56: 2002568.

2 Sikkema RS, Pas SD, Nieuwenhuijse DF, et al. COVID-19 in health-care workers in three hospitals in the south of the Netherlands: a cross-sectional study. Lancet Infect Dis 2020; in press [https://doi.org/10.1016/S1473-3099(20) 30527-2].

3 Ortega R, Gonzalez M, Nozari A, et al. Personal protective equipment and Covid-19. N Engl J Med 2020; 382 : e105.

4 World Health Organization. Coronavirus Disease (COVID-19) Situation Report - 82. www.who.int/docs/ default-source/coronaviruse/situation-reports/20200411-sitrep-82-covid-19.pdf?sfvrsn=74a5d15_2 Date last updated: 11 April 2020. Date last accessed: 16 July 2020. 
5 World Health Organization. Coronavirus Disease (COVID-19) Situation Report - 160. www.who.int/docs/defaultsource/coronaviruse/situation-reports/20200531-covid-19-sitrep-132.pdf?sfvrsn=d9c2eaef_2 Date last updated: 28 June, 2020. Date last accessed: 16 July 2020.

6 Comunicado técnico diario. Secretaría de Salud Federal. 1 de julio, 2020. https://coronavirus.gob.mx/2020/07/01/ conferencia-1-de-julio/ Date last updated: 1 July 2020. Date last accessed: 24 July 2020.

7 Televisa News. Suman 683 Trabajadores de Salud Muertos por Coronavirus en México, July 1, 2020. https:// noticieros.televisa.com/ultimas-noticias/suman-683-trabajadores-de-salud-muertos-por-coronavirus-en-mexico/. Date last updated: 1 July 2020. Date last accessed: 24 July 2020.

8 Bielicki JA, Duval X, Gobat N, et al. Monitoring approaches for health-care workers during the COVID-19 pandemic. Lancet Infect Dis 2020; 20: E261-E267.

Copyright CERS 2020.

This version is distributed under the terms of the Creative Commons Attribution Non-Commercial Licence 4.0. 